\title{
Separate Effects Test Stand for Obtaining Hydrotransport Data
}

\author{
C. H. Allen
}

August 1980

Prepared for the U.S. Department of Energy under Contract DE-AC06-76RLO 1830

Pacific Northwest Laboratory

Operated for the U.S. Department of Energy

by Battelle Memorial Institute 
NOTICE

This report was prepared as an account of work sponsored by the United States Government. Neither the United States nor the Department of Energy, nor any of their employees, nor any of their contractors, subcontractors, or their employees, makes any warranty, express or implied, or assumes any legal liability or responsibility for the accuracy. completeness or usefulness of any information, apparatus, product or process disclosed, or represents that its use would not infringe privately owned rights.

The views, opinions and conclusions contained in this report are those of the contractor and do not necessarily represent those of the United States Government or the United States Department of Energy.

\author{
PACIFIC NORTHWEST LABORATORY \\ operated by \\ BATTELLE \\ for the \\ UNITED STATES DEPARTMENT OF ENERGY \\ Under Contract DE-AC06-76RLO 1830
}

\author{
Printed in the United States of America \\ Available from \\ National Technical Information Service \\ United States Department of Commerce \\ 5285 Port Royal Road \\ Springfield, Virginia 22151
}

Price: Printed Copy $\$$ $\therefore$ Microfiche $\$ 3.00$

NTIS

-pages Selling Price

001-025 \$4.00

026-050 \$4.50

051-075 \$5.25

$076-100 \quad \$ 6.00$

$101-125 \quad \$ 6.50$

$126-150 \quad \$ 7.25$

$151-175 \quad \$ 8.00$

$176-200 \quad \$ 9.00$

$201-225 \quad \$ 9.25$

$226-250 \quad \$ 9.50$

$251-275 \quad \$ 10.75$

$276.300 \quad \$ 11.00$ 


\section{4}

SEPARATE EFFECTS TEST STAND
FOR OBTAINING HYDROTRANSPORT DATA

C. H. Allen

August 1980

Prepared for the

U.S. Department of Energy

under Contract DE-ACO6 -76RLO 1830

Pacific Northwest Laboratory

Richland, Washington 99352 


\section{ACKNOWLEDGEMENTS}

This work was performed under the direction of Anthony J. Miscoe of the Department of Energy, Pittsburgh Mining Operations Center. I would like to express my appreciation to Les Pedersen for his assistance with the project; Walt Jackson for his design/drafting services; Leonard Shotwell for his operating assistance; and Edye Jenkins for her editing services, all of PNL. 


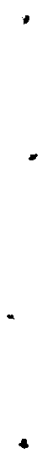


Based on earlier hydrotransport research by English and Russian researchers, a special test stand has been designed and constructed to obtain data to determine hydraulic drag, pipe wear, and comminution of particles. These data are intended for design and separate-effects operating information. This information will be used to supplement data developed by the Hydrotransport Research Facility located at the Pittsburgh Mining Operations, Pittsburgh, Pennsyivania. This report describes the equipment as designed, explains how the hydraulic drag is calculated using test-stand data, and presents some pre1 iminary tests results using water. Tests using water are continuing to further substantiate the system and later, tests will be started using slurries. 


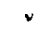




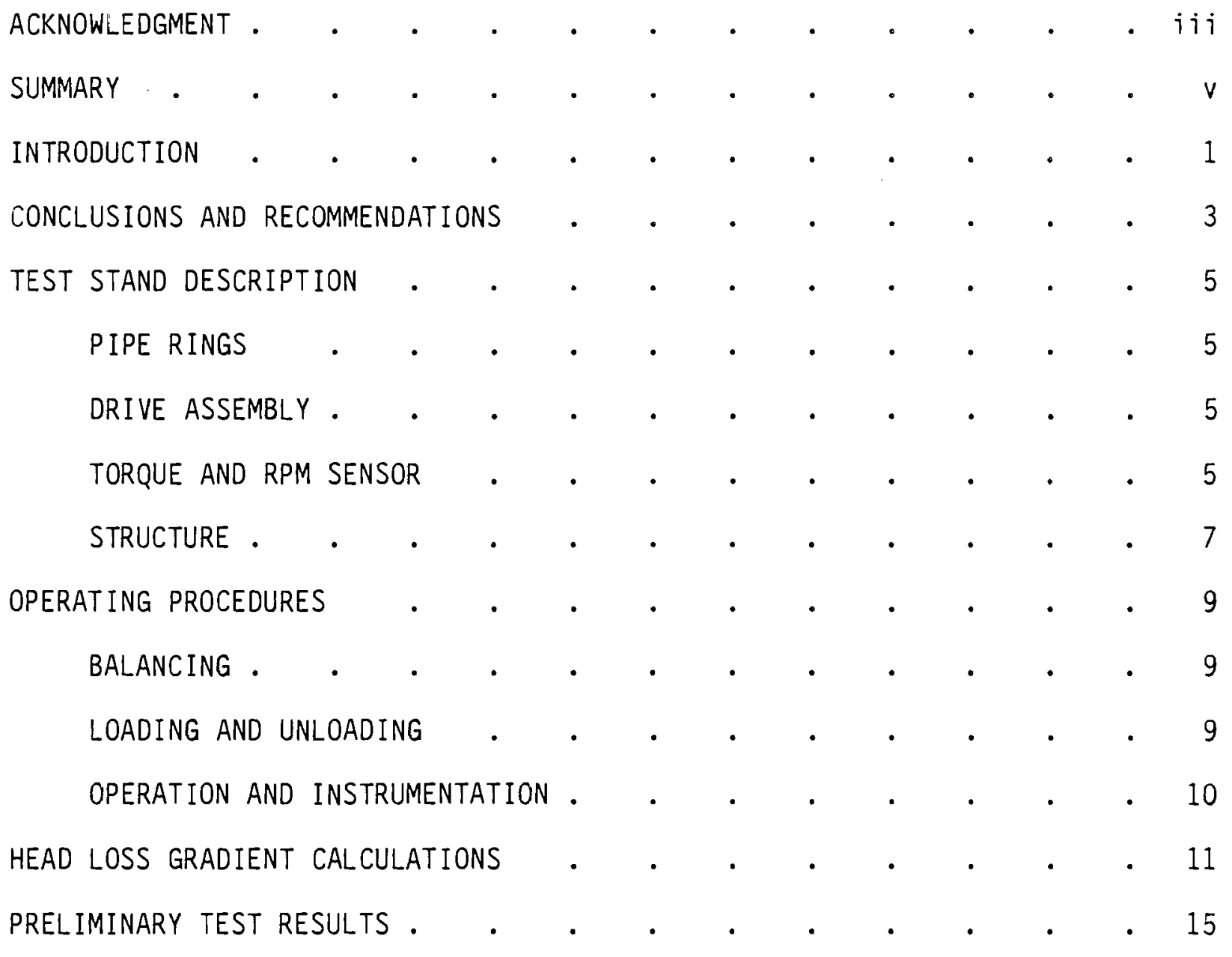




\section{FIGURES}

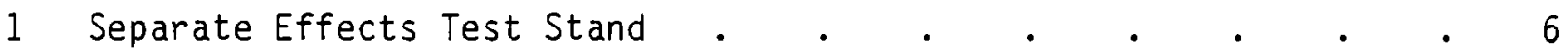

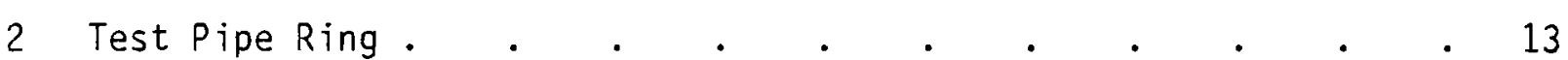

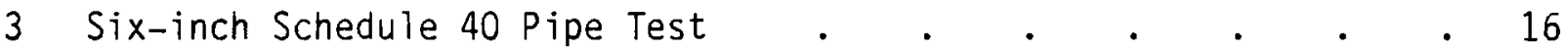

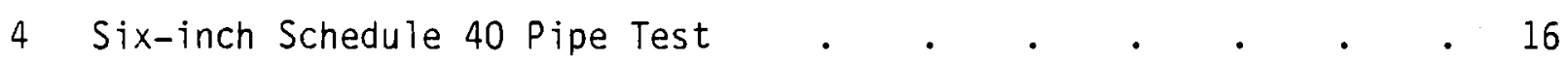

5 Eight-inch Schedule 40 Pipe Test . . . . . . . . 17 


\section{SEPARATE EFFECTS TEST STAND}

FOR OBTAINING HYDROTRANSPORT DATA

\section{INTRODUCTION}

This report describes the first year's research conducted by the Pacific Northwest Laboratory (PNL) a to design, build, and test a Separate Effects Test Stand (SETS), which will be used to obtain coal-slurry hydrotransport data. This research has been conducted in response to interest generated by the Department of Energy in the English translation of the Russian book, Parameters and Regimes of Hydraulic Transportation of Coal by Pipelines (Trainis 1970) and an earlier paper by Worster and Denny (1955).

During normal transport of coal slurry, the coal slurry moves through a stationary pipe. However, theory indicates the turbulent flow that is characteristic of the coal slurry at the slurry-pipewall interface is the important pipewall-wear characterization zone, and that this zone is controlled by relative motion, and not the component of the system that is in motion.

The SETS is valuable to the study of pipeline wear under transport conditions with run-of-mine coal in underground mines, as well as long-haul slurry pipelines. An important advantage of the SETS is that it is a closed-loop system, which allows important parameters of coal-slurry transport to be accurately and independently measured using reasonable quantities of slurry.

The wheel test stand, as described by the Russians, consists of a pipe bent into a wheel with spokes that attach the wheel vertically to an axle for support. To use the test stand in normal operation, the wheel is filled with slurry to approximately one-third its capacity. The wheel is then rotated at a constant speed so the slurry remains stationary in the lower section of the wheel as the pipewall moves by; the rotational speed of the wheel is 1 imited to speeds where the gravitational force of the displaced slurry is balanced by the frictional force, restricting the further movement of slurry in the pipe.

(a) Operated by Battelle Memorial Institute 
The Russians preferred the wheel-stand testing method for making specific measurements to a full-scale, loop-type test facility because it is more economical to construct and operate, experiments using it are simple to run and require only a small inventory of slurry, and results from the tests can be obtained more quickly. Four parameters of hydrotransport were studied by the Russians:

1. Hydraulic drag (pressure drop) was measured by determining the power consumption by first rotating the wheel empty, and then rotating the wheel when filled with slurry. The difference in power consumption, as well as the flow rate, were used to calculate the drag per length of wetted surface at relative velocities.

2. Critical velocity (settling velocity) was determined, using visual observations of the slurry through a transparent pipe, using noise produced by particles that settle and rub along the surface of the pipe, and using fluctuations of power input to the wheel test stand.

Trainis (1970) indicated that slurry velocities of up to $6 \mathrm{~m} / \mathrm{sec}(19.7 \mathrm{ft} /$ $\mathrm{sec}$ ) can be obtained using 0.20-m (8-in.) diameter pipe in a 2.6-m (9.5-ft) diameter wheel. In addition, the Russians collected data using a slurry velocity of $4 \mathrm{~m} / \mathrm{sec}(13.1 \mathrm{ft} / \mathrm{sec})$. Both velocities were within the predicted range for run-of-mine coal transport.

3. Pipewall wear was determined by weighing sections of the pipe in the wheel stand before and after the tests.

4. Comminution of particles during transport were determined by size classification of the particles in the slurry charges before and after the tests.

Coal-particle comminution has been recognized as a major contributor to error in the results obtained during closed-loop tests by containing pumps, reservoir tanks, etc. The wheel test stand overcomes this problem because it does not use a pump; particle comminution in pumps is twice as great as that occurring in the transport pipe. 
CONCLUSION

The results of the preliminary testing done by PNL indicate close correlation between our data and the reference data, and the methods appear valid for determining head loss gradient using water. 


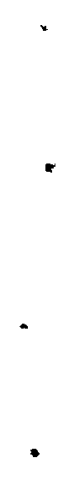




\section{TEST STAND DESCRIPTION}

Pacific Northwest Laboratory researchers designed and procured the test stand, which consists of four major parts. Figure 1 shows the test stand as constructed, with the components identified. The following sections describe the major components.

\section{PIPE RING}

Four $90^{\circ}$ segments of schedule 40 test pipe are fabricated into a circle. The maximum outside diameter of a test pipe is 4.26 (14 ft), as determined by the dimensions of our facility. The segments are connected using bolted-on couplings. To date, pipes of $0.10-m\left(4-i_{.}\right), 0.15-m\left(5-i n_{\text {. }}\right)$ and $0.20-m$ (8-in.) inside diameter, have been fabricated into rings of various diameters for testing. The test stand was designed to handle pipe with inside diameters up to $0.45 \mathrm{~m}$ (18 in.); a $0.30-\mathrm{m}-\mathrm{ID}\left(12-\mathrm{in}_{\text {. }}\right)$ pipe is now on order for testing. Each ring has two plugged openings for filling and emptying the pipe.

The pipe rings are bolted to the wheel frame using standard "U" bolt pipe hangers.

\section{DRIVE ASSEMBLY}

The drive assembly rotates the pipe circle at the desired speed set. It consists of a 10-hp, variable speed dc motor, a gear reducer, and a torque-rpm sensor that is coupled to the $10.16-\mathrm{cm}(4-\mathrm{in}$.$) wheel shaft. The wheel and$ shaft are supported by two large roller bearings.

This drive system can turn a pipe ring mounted on the machine at any rpm from 0 to 68 . This maximum speed is equivalent to $6.70 \mathrm{~m} / \mathrm{sec}(22 \mathrm{ft} / \mathrm{sec})$ using a 1.83-m pipe ring. The drive is capable of accelerating the maximum load from rest to $68 \mathrm{rpm}$ in $30 \mathrm{sec}$.

\section{TORQUE AND RPM SENSOR}

The torque sensor with readout is sized to read the torque required to drive the wheel, and can measure torque to $230.4 \mathrm{~kg}-\mathrm{m}(20,000 \mathrm{lb}-\mathrm{in}$.$) . The$ 


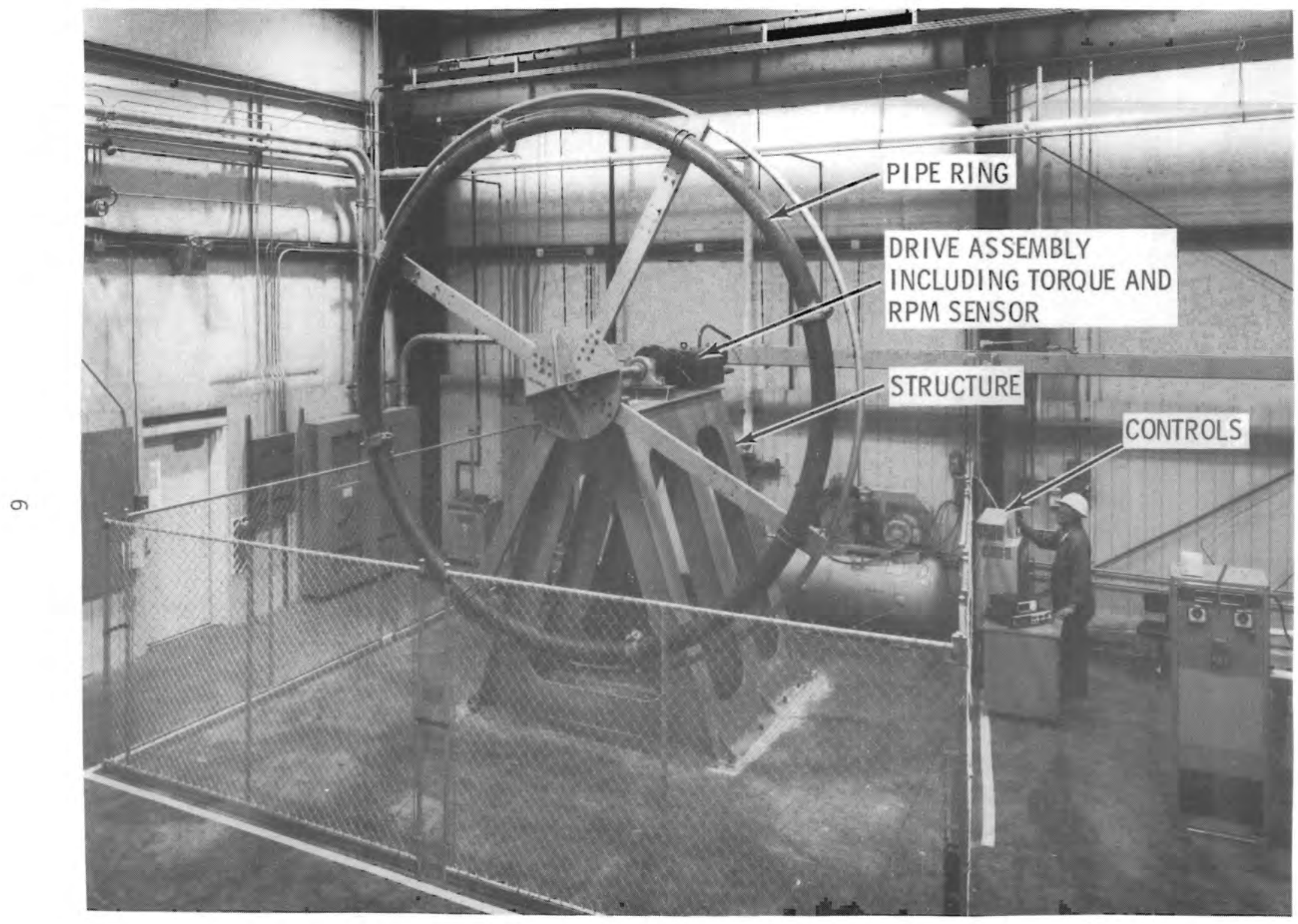

FIGURE 1. Separate Effects Test Stand 
torque sensor with a digital readout is calibrated to $\pm 0.1 \%$ full-scale referable to the National Bureau of Standards. The torque meter is also equipped with an rpm sensor with digital readout. Chart recording equipment can also be connected for both torque and rpm measurements.

\section{STRUCTURE}

The structure supports the drive assembly, shaft bearings and spoke-wheel arrangement that supports the pipe circle. The structure is a steel weldment of suitable weight and geometry to safely support all loads. The main wheel shaft and bearings are sized to support the wheel as an overhung load with minimum shaft deflection. The spoked wheel arrangement is designed for ease of pipe-ring changes.

A 1.82-m-high fence surrounding the test stand protects personnel from moving parts. 


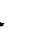

.

.

. 


\section{OPERATING PROCEDURES}

The following directions outline the procedures used during normal operation of the SETS.

\section{BALANCING}

Before the test wheel is rotated with a test pipe in place, the wheel assembly is statically balanced using a balancing stand. The wheel with an empty test-pipe ring attached is held by an overhead traveling crane and a balancing hub is attached to the wheel. The assembly is then lowered onto the balancing stand using the crane, and bolts are attached or removed to balance the assembly.

\section{LOADING AND UNLOADING}

Two methods can be used to load and unload the SETS with water or slurry. The first method, which is discussed in detail below, requires a quarter section of the pipe to be removed. An alternative method requires pipe tees and plugs or blind flanges to be installed in the pipe. Solid materials are loaded and unloaded manually into the SETS.

Before a quarter section of the pipe can be removed for loading and unloading, the wheel must be jogged until the quarter section lies in its top position; the electrical power to the drive must then be locked out. The pipe connectors that attach the quarter section of pipe to the other sections of pipe are removed, as well as the pipe clamps, and the quarter section is lifted off the wheel using a sling attached to an overhead-traveling crane.

Once the quarter section of pipe has been removed, water or slurry can be loaded into the SETS using a weighed or known-volume container that is suspended by the overhead-traveling crane. A temporary construction scaffold $3.05 \mathrm{~m}$ in height facilitates this process. When the testing is completed, the water or slurry is emptied from the wheel into a catch-tray beneath the SETS structure. 
OPERATION AND INSTRUMENTATION

Startup of the SETS is at maximum acceleration time (30 sec). Initial running speed is kept low (not over $10 \mathrm{rpm}$ ). Any unexplained vibration, noise, or movement is a signal for the operator to immediately shut down the SETS until the problem is diagnosed and corrected. After the low-rpm checkout, the SETS speed is increased by turning the speed control knob to the rpm required by the test (maximum $68 \mathrm{rpm}$ ).

Torque and rpm are read from the digital display. These signals can be connected to a strip chart recorder for recording and later analysis.

No personnel are allowed inside the fenced SETS enclosure during starting, running or stopping. 
The method used to calculate the head loss gradient at various constant velocities is simple and direct and uses the following nomenclature.

\begin{tabular}{|c|c|c|}
\hline Symbol & Units & Description \\
\hline & $\mathrm{m} / \mathrm{s}$ & $\begin{array}{l}\text { Relative linear velocity between the moving } \\
\text { pipe and the fluid }\end{array}$ \\
\hline D & $\mathrm{m}$ & ID of pipe \\
\hline A & $m^{2}$ & Flow cross-section \\
\hline$L_{W}$ & $\mathrm{~m}$ & Wetted pipe length \\
\hline$R$ & $\mathrm{~m}$ & Centerline radius of test pipe ring \\
\hline$T_{w}$ & $\mathrm{~kg}-\mathrm{m}$ & Torque (wet); test pipe containing fluid(a) \\
\hline$T_{d}$ & $\mathrm{~kg}-\mathrm{m}$ & Torque (dry); test pipe empty(b) \\
\hline$T$ & $\mathrm{~kg}-\mathrm{m}$ & Torque caused by drag of fluid \\
\hline$\rho$ & $\mathrm{kg}-\mathrm{m}^{3}$ & Density of fluid \\
\hline rpm & & Revolutions per min of whee 1 \\
\hline$H$ & $m$ of fluid & Head \\
\hline$i$ & $\begin{array}{l}\mathrm{m} \text { of fluid/m } \\
\text { (normally m } \\
\text { of } \mathrm{H}_{2} \mathrm{O} / \mathrm{m} \text { ) }\end{array}$ & Head loss gradient \\
\hline
\end{tabular}

During a test, the linear velocity of water relative to that of the pipe in $\mathrm{m} / \mathrm{sec}$, is calculated from:

$$
V=\frac{2 R \pi(R P M)}{60}
$$

(a) Measure of torque caused by friction of fluid (drag) plus bearing and air friction and any imbalance in the system.

(b) Measure of torque caused by bearing and air friction and any imbalance in the system. 
Torque (T) measurements are taken at various constant velocities before the head loss gradient can be calculated. First, the torque $\left(T_{d}\right)$ required to turn the empty test wheel and test pipe at various constant velocities is measured. Next, the torque $\left(T_{w}\right)$ required to rotate the test wheel and test pipe when filled with a known amount of water or slurry at the same constant velocities is recorded. The difference between these two recordings is the measure of torque ( $T$ ) required to overcome the drag caused by the fluid in the pipe at that relative velocity.

The method used to calculate the head loss gradient ( $i$ ) using the torque ( $T$ ) measurement is shown in Figure 2 and explained below. At a constant rotational speed, a head $(H)$ of fluid develops that is equal in weight to the drag forces and keeps the drag forces in equilibrium. (a) Because the drag is higher on the longer outer surface of the pipe than on the inner surface, the fluid tends to form the pattern shown by the dotted line in Figure 2 , and this shape makes it difficult to measure the head $(H)$ directly even through clear pipe. Finding the torque $(T)$ is a means of measuring the head, as the torque is equal to the weight of fluid with a head $(H)$ times the radius $(R)$ of the test pipe:

$$
T_{w}-T_{d}=T=\frac{\pi D^{2} \rho}{4} H R
$$

where

$$
\pi D^{2} / 4 \text { is the flow cross section of the test pipe }(A) \text {. }
$$

Equation 1 can be solved for $H$, giving:

$$
H=\frac{4 T}{\pi D^{2} R_{\rho}}
$$

\footnotetext{
(a) If the velocity (rpm) becomes high enough, the drag forces become high enough to distribute the fluid around the pipe, and the fluid travels with the pipe as centrifical forces control.
} 


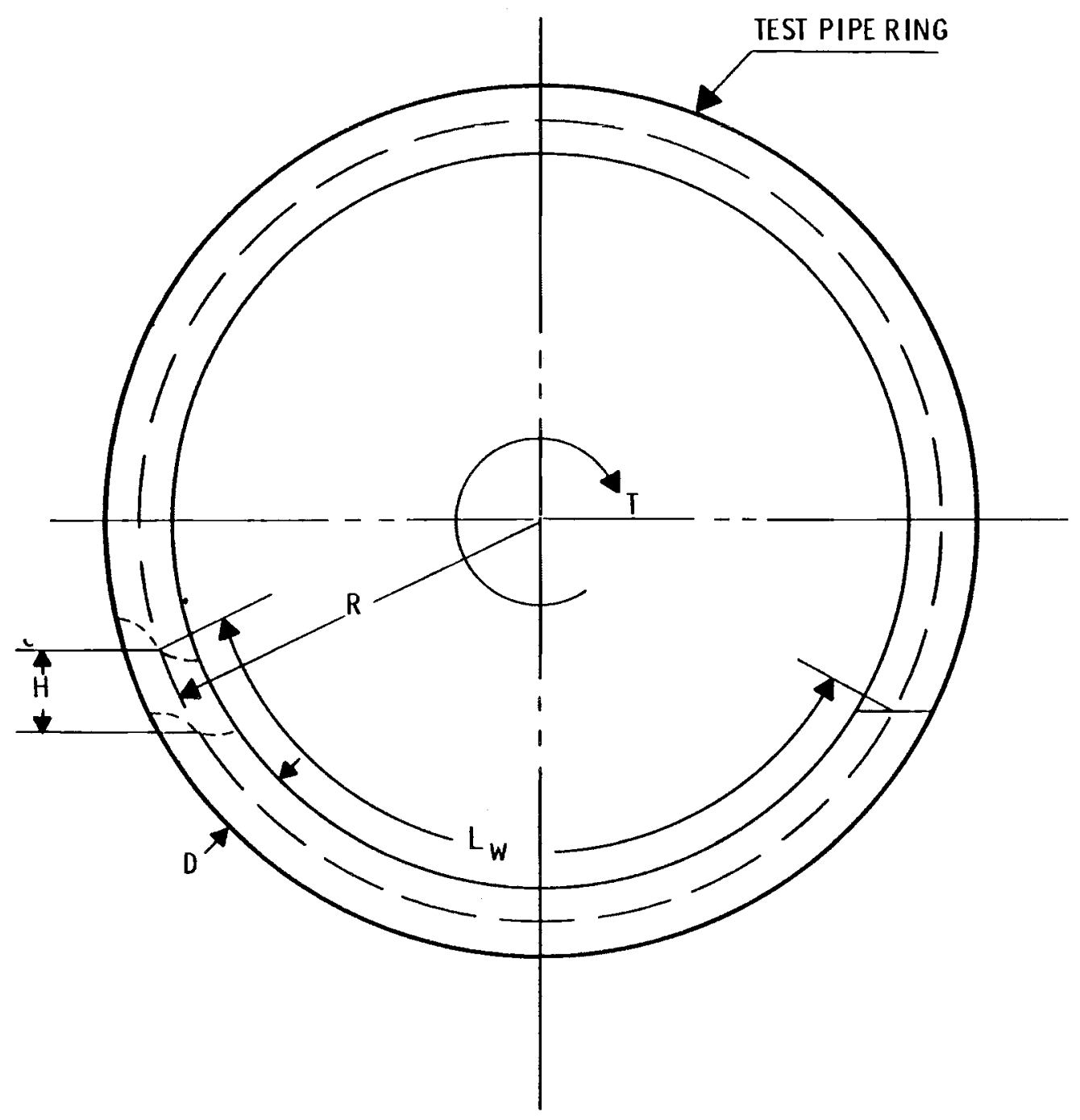

FIGURE 2. Test Pipe Ring 
To obtain the head loss gradient $(i)$, the head $(H)$ is divided by the wetted pipe length $\left(L_{w}\right)$ :

$$
i=\frac{H}{L_{W}}
$$

To obtain the head loss gradient for fluids other than water, meters of fluid would be converted to meters of water:

$$
i \frac{\rho_{\text {fluid }}}{\rho_{\text {water }}}=i \frac{\mathrm{m} \text { of } \mathrm{H}_{2} \mathrm{O}}{\mathrm{m} \text { of fluid }}
$$




\section{PRELIMINARY TESTING RESULTS}

The test stand was operated and preliminary data taken to check the operation and to determine the general validity of the system.

Two tests using schedule 40 pipe with an inside diameter of $0.15 \mathrm{~m}$ ( 6 in.) in $2.88-\mathrm{m}(9.45-\mathrm{ft})$ and $4.10-\mathrm{m}(13.45-\mathrm{ft})$ outside diameter rings and one test using schedule 40 pipe with an inside diameter of $0.20 \mathrm{~m}(8 \mathrm{in}$.$) in a 3.79-\mathrm{m}$ $(12.43-\mathrm{ft})$ outside diameter $r$ ing have been conducted. These tests were made filling the pipe with water to one-fourth, one-third and one-half its capacity. The resulting head loss gradient at various velocities was graphed and the data was compared to a head loss gradient graph in a reference handbook. The graphs are shown in Figures 3, 4, and 5, and should be considered preliminary, as only two runs have been made and averaged. Torque data has been developed using an average of the maximum and minimum digital readings at each velocity ( $\mathrm{rpm}$ ). The torque measurements vary because of system imbalance, which the sensitive strain-gauge torque sensor system detects. Future tests will use a chart recording from which an average torque measurement can be readily obtained.

This preliminary data indicates that one larger-diameter pipe ring provides better correlation with the reference data than one smaller-diameter pipe ring. During these preliminary tests, no significant difference was seen when testing the pipes filled with water to one-fourth, one-third or one-half their capacities. 


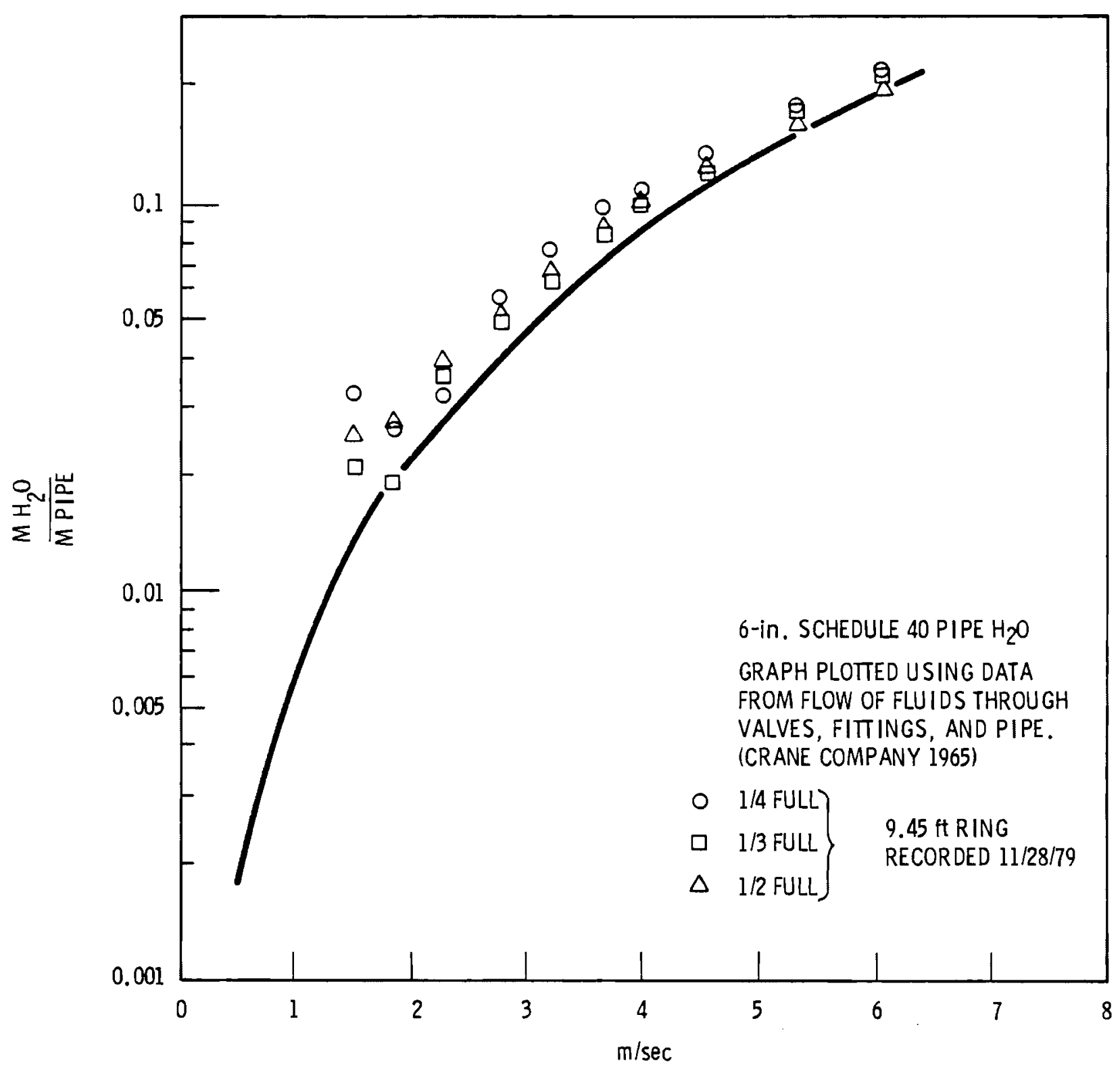

FIGURE 3. Six-Inch Schedule 40 Pipe Tests Using Water, 9.45-Foot Ring 


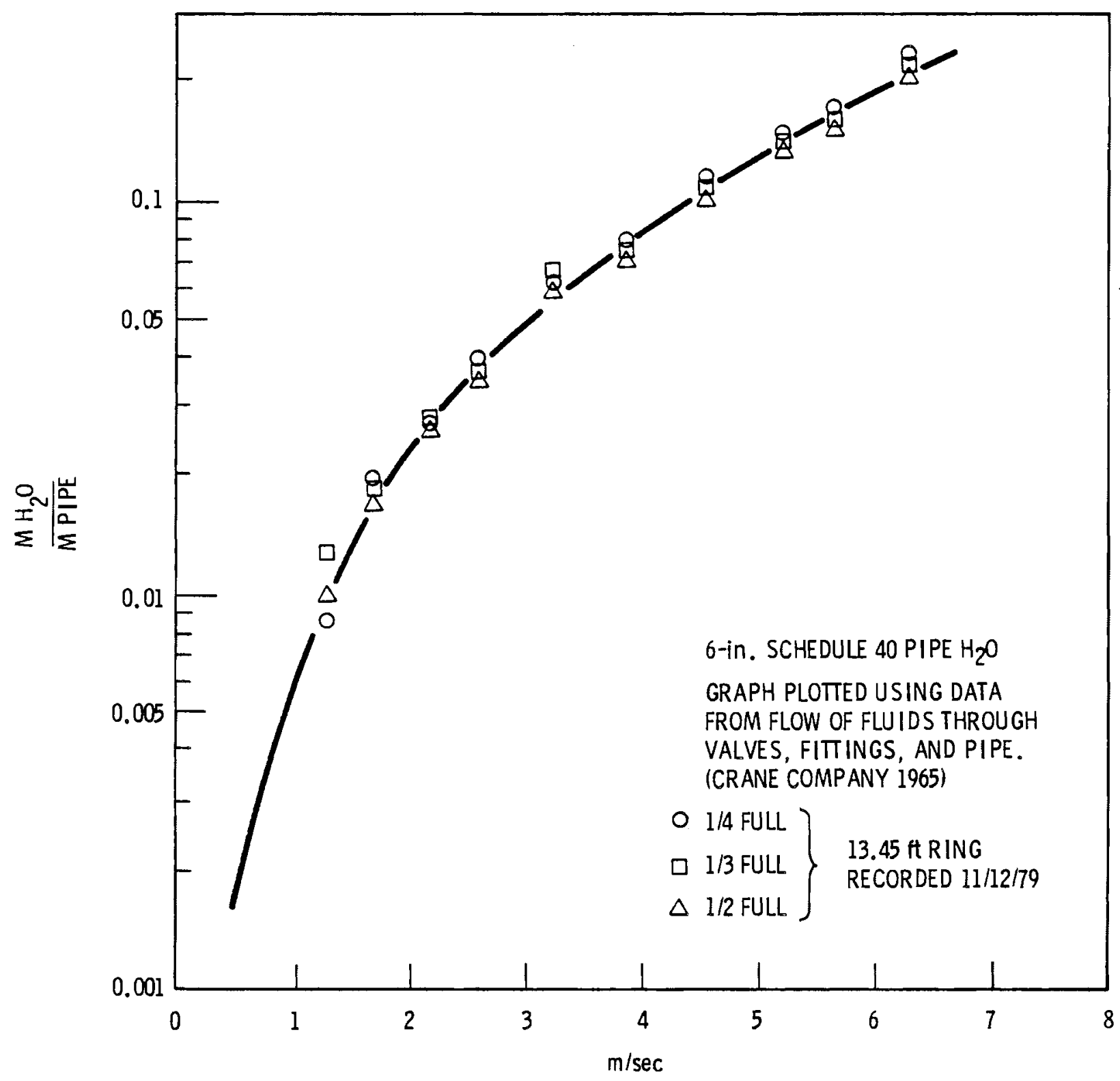

FIGURE 4. Six-Inch Schedule 40 Pipe Tests Using Water, 13.45-Foot Ring 


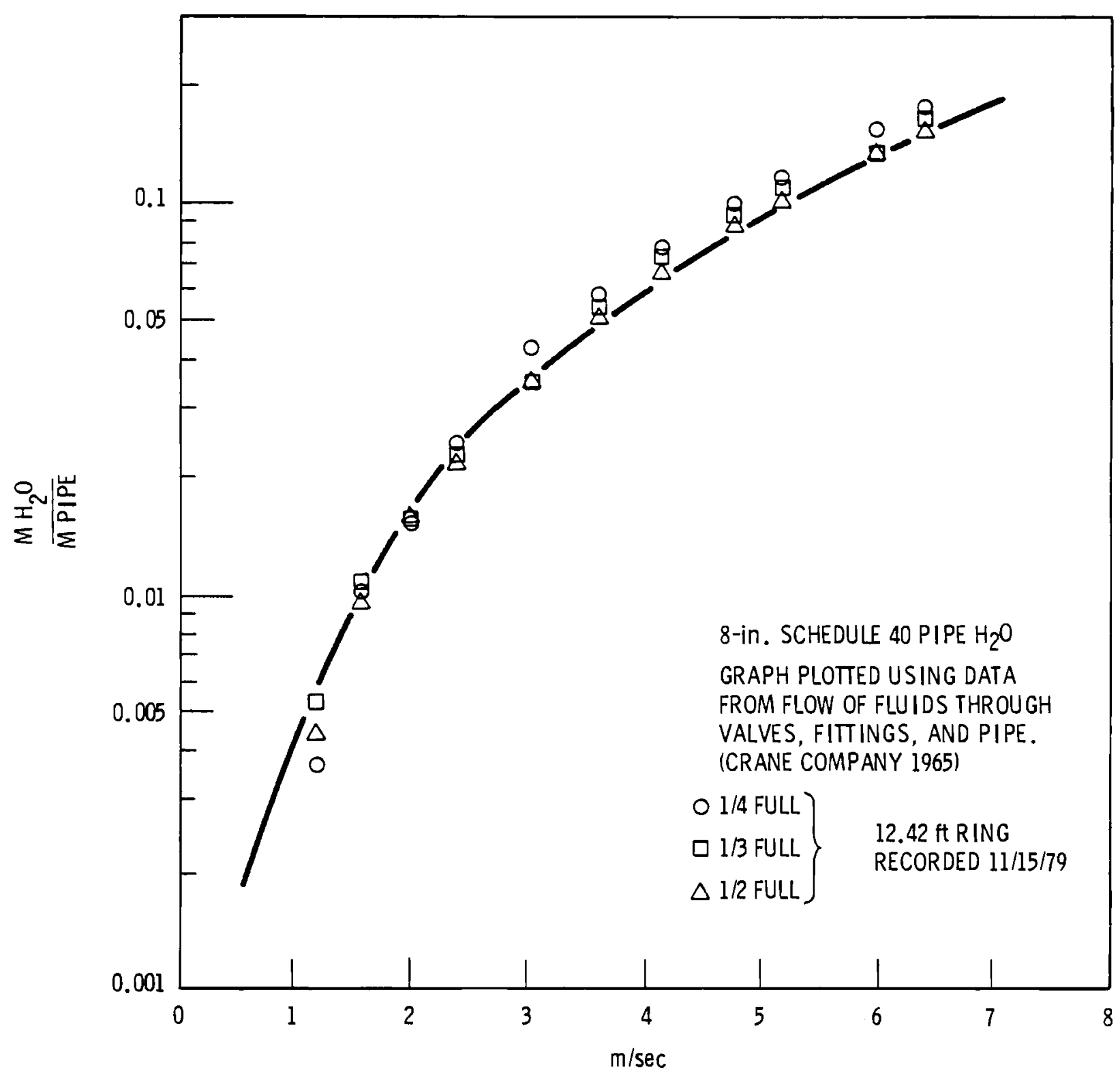

FIGURE 5. Eight-Inch Schedule 40 Pipe Tests Using Water, 12.42-Foot Ring 


\section{REFERENCES}

Crane Company. 1965. Crane Technical Paper No. 410. 9th ed. Appendix B, p. 14. Chicago, Illinois.

Trainis, V. V. 1976. C Parametry I Rezhimy Gidravlicheskogo Transportirovaniya UgTya Po Truboprovodam. (Translated by the U.S. Buroau of Mines. 1976. Parameters and Regimes for the Hydraulic Transportation of Coal by Pipelines. Washington, DC) PB280986, National Technical Information Service, Springfield, Virginia.

Worster, R. C., and D. F. Denny. 1955. "Hydraulic Transport of Solid Materials in Pipes." Inst. Mech. Engr. Proc. 169:563-568. 
, 


\section{DISTRIBUTION}

No. of

Copies

OFFSITE

A. A. Churm

DOE Patent Division

9800 S. Cass Ave.

Argonne, IL 60439

DOE Office of Fossil Fuels

Washington, DC 20545

Anthony J. Miscoe

Supervisory Mechanical Engineer

DOE Pittsburgh Mining Operations

Center

4800 Forbes Ave.

Pittsburgh, PA 15213

Eugene Palowitch

Director

DOE Pittsburgh Mining Operations

Center

4800 Forbes Ave.

Pittsburgh, PA 15213

William Schmidt

Director

Office of Coal Mining

Division of Fossil Fuel Extraction

U.S. Department of Energy, D-107

Washington, DC 20545

27 DOE Technical Information Center
No. of

Copies

ONSITE

DOE Richland Operations Office

H. E. Ransom

42 Pacific Northwest Laboratory

C. Allen (25)

L. Pederson

W. Enderlin

W. Kelly

M. Morgenstern

T. Powers

L. Eyler

T. Sutey

N. Lombardo

J. Haverfield

E. Jenkins

Technical Information (5)

Publishing Coordination SH (2) 
